\title{
Reduction of Total Chromium Levels from Raw Tannery Wastewater via Electrocoagulation using Response Surface Methodology
}

\author{
Edwar Aguilar-Ascón ${ }^{1 *}$, Liliana Marrufo-Saldaña ${ }^{2}$, Walter Neyra-Ascón ${ }^{1}$ \\ 1 Universidad de Lima, Instituto de Investigación Científica (IDIC), Av. Javier Prado 4600, Surco, Lima, Perú \\ 2 Centro de Innovación Productiva y Transferencia Tecnológica del Cuero, Calzado e Industrias Conexas \\ (CITEccal Lima) - ITP, Av. Caquetá 1300, Rímac, Lima, Perú \\ * Corresponding author's e-mail: eaguilaa@ulima.edu.pe
}

\begin{abstract}
This study focused on reducing total chromium levels in raw wastewater from the leather tanning industry via electrocoagulation to comply with maximum permissible limits (MPL) and to determine the effects of main process parameters. An electrocoagulation reactor was built using aluminum electrodes as an anode and cathode. Then, the response surface methodology was applied using a $3^{\mathrm{k}}$ factorial design considering three factors, namely current intensity, treatment time, and $\mathrm{pH}$. The total chromium removal percentage was considered as a response variable. $99 \%$ of the total chromium found in wastewater could be removed after 14-min treatment at 2-A current intensity and $\mathrm{pH}$ 5.5. Similar amount of chromium was removed at $\mathrm{pH}$ of 8.5 and 7. Statistical analysis performed at a confidence level of $p<0.05$ revealed that all three factors influenced electrocoagulation. Total chromium could be efficiently removed from raw wastewater at a current intensity of $2.9 \mathrm{~A}$, a pH of 8.4, and a treatment time of $21 \mathrm{~min}$, suggesting that electrocoagulation using aluminum electrodes is an efficient method for total chromium removal. Thus, this process must be considered as a solution to the problems caused by the leather tanning industry and for better compliance with the MPL established in the Peruvian environmental standards.
\end{abstract}

Keywords: chromium, electrocoagulation, tannery wastewater, aluminum electrodes, response surface.

\section{INTRODUCTION}

The leather tanning industry has gained attention because a variety of products are produced from hides of animals. Leather is made via three processes, namely beamhouse operations, tanning, and finishing. Among these processes, beamhouse operations and tanning requires large water amounts, generating large pollutant loads. Therefore, these wet processes are usually conducted in countries with flexible environmental regulations. Official data from the Ministry of Production of Peru suggest that leather production in 2017 increased to approximately $1,900,000$ square feet. In addition, for each ton of leather produced, $45-50 \mathrm{~m}^{3}$ of effluents are generated [Kanagarak, 2014]. These effluents are characterized by high salinity, organic load (high BOD and COD values), suspended solids, ammonium, nitrogen, chloride, chromium, and heavy metal contents [Manjushree, 2013]. Chromium is the main tanning agent used for $\sim 95 \%$ of the national leather production (CITEcall). A considerable percentage of the total amount of chromium used for chrome tanning is released as effluents. In fact, only $\sim 50 \%$ of the chromium is effectively adhered to the skin [Bacardit, 2008].

Chromium is an essential trace element for humans and animals but not for plants. Two stable chromium forms, namely trivalent chromium $(\mathrm{Cr}(\mathrm{III}))$ and hexavalent chromium $(\mathrm{Cr}(\mathrm{VI}))$, can be found in the environment. $\mathrm{Cr}(\mathrm{VI})$ is extremely toxic as it easily crosses biological membranes and can be actively transported inside cells via a sulfate transporter [Gutiérrez, 2010]. In fact, $\mathrm{Cr}(\mathrm{VI})$ has been considered by the International Agency for Research on Cancer as group I carcinogen, whereas $\mathrm{Cr}(\mathrm{III})$, is relatively harmless in solution and immobile when forming an insoluble hydroxide. However, in high concentrations, 
$\mathrm{Cr}(\mathrm{III})$ may present the same toxic effects as Cr(VI) [Gutiérrez, 2010]. Discharge water containing high chromium concentration may oxidize $\mathrm{Cr}$ (III) to $\mathrm{Cr}(\mathrm{IV})$ because of the presence of oxidizing agents such as oxygen, manganese(VI), and iron(III). Different removal techniques have been proposed for raw tannery wastewater treatment, including chemical precipitation, adsorption and using biomaterials.

Electrocoagulation is as an alternative to conventional raw tannery wastewater treatments. Then, in 2014, El-Naas reported that $100 \%$ chromium can be removed by increasing current density and conductivity. In 2015, Mella determined that aluminum electrodes successfully removed up to $97 \%$ of total chromium, surpassing $\mathrm{Cu}$ and Fe electrodes in terms of efficiency. In 2016, Elabbas, simultaneously eliminated COD and total chromium in tannery wastewater using aluminum electrodes. Herein, 99\% chromium removal was achieved. However, to supplement the contributions from these studies, electrocoagulation must be assessed using wastewater from Peruvian tanning industries having high degree of contamination and high conductivity values. These characteristics hinder wastewater treatment via electrocoagulation because of high electric current would be required. Herein, total chromium contamination levels in effluents are reduced to comply with the maximum limits allowed for electrocoagulation and to assess how current intensity, treatment time, and $\mathrm{pH}$ influence the process.

Electrocoagulation is a process where the sacrificial anode is oxidized, releasing metal ions, and the cathode is reduced, forming hydroxyl ions via hydrolysis. Metal ions combine with hydroxyl ions to form metal hydroxide compounds (coagulants), which support the formation of floccules by destabilizing suspended colloidal particles. Depending on their density, the resulting floccules can be separated from the liquid via flotation or sedimentation [Bensadok et al., 2007; Mella, 2013]. The reactions that occur in an electrochemical cell with a metal (Al) acting as a sacrificial electrode are shown below [Hamdan, 2014]:

At the anode:

$$
A l \rightarrow A l^{3+}+3 e
$$

At the cathode:

$$
3 \mathrm{H}_{2} \mathrm{O}+3 e \rightarrow \frac{3}{2} \mathrm{H}_{2}(g)+3 \mathrm{OH}^{-}
$$

In the solution:

$$
\mathrm{Al}^{3+}(a q)+3 \mathrm{H}_{2} \mathrm{O} \rightarrow \mathrm{Al}(\mathrm{OH})_{3}+3 \mathrm{H}^{+}(a q)
$$

\section{MATERIALS AND METHODS}

\section{Wastewater characterization}

The industrial effluents generated from the leather tanning processes conducted at the Center for Technological Innovation in Leather, Footwear and Related Industries (CITEccal) pilot treatment plant were treated under actual treatment conditions were used as a control point. This wastewater was subjected to an initial physicochemical and microbiological characterization because such wastewaters have high conductivity because of the large amounts of salts used for tanning via electrocoagulation.

\section{Electrocoagulation reactor}

The reactor used was a clear acrylic batch reactor of $20 \times 15 \times 25 \mathrm{~cm}^{3}$ and capacity for treating six liters of wastewater. We used four aluminum electrodes for the anode (sacrifice) and four electrodes for the cathode. These electrodes were $10-\mathrm{cm}$ wide, $10-\mathrm{cm}$ long and had an area of $100 \mathrm{~cm}^{2}$. Because of high conductivity, we used a serial configuration and spaced the plates at $2 \mathrm{~cm}$ to reduce electric current requirements. Figure 1 schematizes the configuration of the electrodes in the reactor.

\section{Experimental tests}

Experimental tests were performed at three $\mathrm{pH}$ levels: natural wastewater $\mathrm{pH}$, neutral, and acidic. For each stage, current intensity varied at 1, 2 and $3 \mathrm{~A}$ and samples were taken after 0,7 , 14 and $21 \mathrm{~min}$. To measure $\mathrm{pH}$, conductivity, and temperature, an Oakton PCS 35 multi-parameter was used. To measure total chromium content, the EPA 200.8 method was used. The percentage of total chromium removed was determined as follows:

$$
Y_{n}=\% R=\left(\frac{C r_{i}-C r_{f}}{C r_{i}}\right) \times 100
$$

where: $Y_{n}$ - total chromium removal percentage $\stackrel{n}{C} r_{i}-$ initial total chromium concentration $C R_{f}$ - final total chromium concentration 


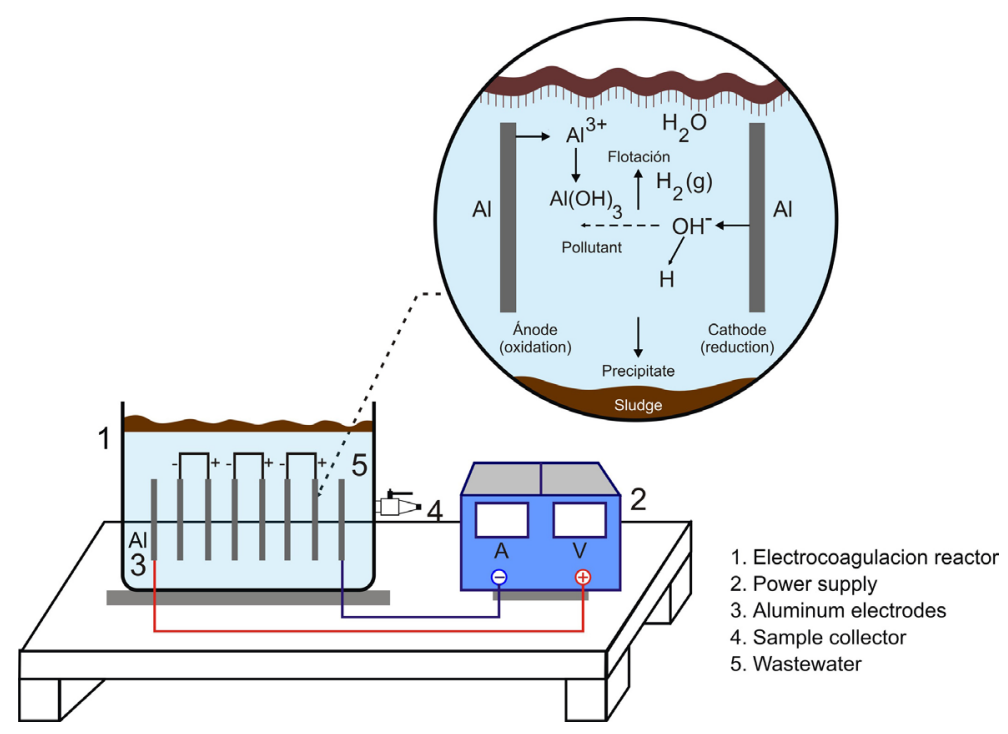

Figure 1. Schematic of electrocoagulation reactor

\section{Experimental design}

Response surface methodology was employed using a $3^{\mathrm{k}}$ factorial design with three factors, three levels and 27 experiments. The factors considered in the design were electric current intensity $\left(\mathrm{x}_{1}\right)$, treatment time, $\left(\mathrm{x}_{2}\right)$ and $\mathrm{pH}\left(\mathrm{x}_{3}\right)$. As a response variable, $\left(\mathrm{y}_{1}\right)$, the percentage of total chromium removal was used (Table 1).

Statistical analysis was performed using Statgraphics Centurion XVI software and Analysis of Variance (ANOVA) with a confidence level of $95 \%$. Equation (5) shows the statistical model used to calculate the independent variables at three $\mathrm{pH}$ levels; therein, $\mathrm{y}_{\mathrm{i}}$ is the experimental response and $x_{i}, x_{j}$ are the independent variables. The quality of the polynomial model was determined by the coefficient of determination $\mathrm{R}^{2}$ and $R^{2}$ adj.

$$
\begin{aligned}
y_{i}= & b_{0}+\sum_{i=1}^{n} b_{i} x_{i}+\sum_{i=1}^{n} b_{i i} x_{i}{ }^{2}+ \\
& +\sum_{i=1}^{n-1} \sum_{j=i+1}^{n} b_{i j} x_{i} x_{j}
\end{aligned}
$$

where: $b_{\sigma^{\prime}} b_{i^{\prime}} b_{i j} y b_{i j}$ - coefficients for linear, quadratic, and second-order interaction, $x_{j} y h_{j}-$ values for the independent variable, $y_{i}-$ total chromium removal percentage.

\section{RESULTS AND DISCUSSION}

Table 2 lists the values from the initial effluent characterization, wherein a total chromium amount of $123.1897 \mathrm{mg} / \mathrm{l}$ and Chromium(III) amount of $123.190 \mathrm{mg} / \mathrm{l}$ were obtained. Here, the Chromium(VI) concentration levels were lower than the detection limit; conductivity was $10430 \mu \mathrm{S} / \mathrm{cm}$.

\section{Effects of current intensity}

Current intensity directly affects process performance. This parameter determines the amount of coagulant produced, microscopic bubble size, and reaction speed, which considerably impact the pollutant removal rate [Hamdan, 2014; Abdalhadi, 2015]. Current intensities of 1, 2, and $3 \mathrm{~A}$ and a fixed electrode surface area of $100 \mathrm{~cm}^{2}$ with a serial connection were used. Figures 2 and 3 show that the chromium removal rate increased with increasing current intensity. Thus, when the current intensity was 2 and 3 A, 99.9\% removal was achieved after 14 min of treatment. These

Table 1. Experimental design Factors and levels

\begin{tabular}{|c|c|c|c|}
\hline Factors & \multicolumn{3}{|c|}{ Levels } \\
\hline$X_{1}:$ Current Intensity (A) & 1 & 2 & 3 \\
\hline$X_{2}:$ Time (min) & 7 & 14 & 21 \\
\hline$X_{3}: \mathrm{pH}$ & 5.5 & 7 & 8.5 \\
\hline
\end{tabular}


Table 2. Physicochemical and biological effluent analysis

\begin{tabular}{|l|c|}
\hline \multicolumn{1}{|c|}{ Parameter } & Value \\
\hline Total chromium ICP $(\mathrm{mg} / \mathrm{L})$ & 123.1897 \\
\hline Chromium III $(\mathrm{mg} / \mathrm{L})$ & 123,190 \\
\hline Chromium VI $(\mathrm{mg} / \mathrm{L})$ & $<0,005$ \\
\hline Conductivity $(\mu \mathrm{S} / \mathrm{cm})$ & 10430 \\
\hline $\mathrm{pH}$ & 8.36 \\
\hline Chloride $(\mathrm{mg} / \mathrm{L})$ & 2104.290 \\
\hline BOD $(\mathrm{mg} / \mathrm{L})$ & 1952.5 \\
\hline COD $(\mathrm{mg} / \mathrm{L})$ & 5308.4 \\
\hline Total Suspended Solids $(\mathrm{mg} / \mathrm{L})$ & 1578 \\
\hline Oils and Fats $(\mathrm{mg} / \mathrm{L})$ & 6.1 \\
\hline Nitrogen $(\mathrm{mg} / \mathrm{L})$ & 352.43 \\
\hline Phosphorus $(\mathrm{mg} / \mathrm{L})$ & 12,525 \\
\hline Total Coliforms $(\mathrm{NMP} / 100 \mathrm{~mL})$ & 49000000 \\
\hline Fecal Coliforms $(\mathrm{NMP} / 100 \mathrm{~mL})$ & 330000 \\
\hline Turbidity $(\mathrm{NTU})$ & 1810.0 \\
\hline Sulfur (mg/L) & 37.7932 \\
\hline
\end{tabular}

results match those reported by Mella in 2015 wherein Al electrodes could remove $97.76 \%$ chromium after applying current intensities of 0-3 A for $110 \mathrm{~min}$. Elabbas argued that the $98.1 \%$ of chromium removal rate was achieved when current density was increased from 200 to $400 \mathrm{Am}^{-2}$ because as current intensity increases, the amount of anodic aluminum dissolution also increases, leading to better coagulation. However, very high current intensity values may decrease efficiency because of oxygen production and electrode passivation [Piña et al., 2011].

\section{Effects of $\mathrm{pH}$}

The initial $\mathrm{pH}$ is important for efficient electrocoagulation because its variation during treatment affects efficiency [Cañizares, 2009; Elabbas, 2015]. The increase in water $\mathrm{pH}$ is mainly attributed to the production of hydroxide ions $\left(\mathrm{OH}^{-}\right)$, which are continuously generated from water reduction in the cathode and the formation of $\mathrm{Al}(\mathrm{OH})_{3}$ [Elabbas, 2015]. Aluminum electrodes remove chromium because of their high $\mathrm{Al}(\mathrm{OH})_{3}$ formation rate, generating floccules that behave as chromium ion adsorbents. In Figures 2 and 3 , at a $5.5 \mathrm{pH}$ and three current intensities after 7-min treatment, 90\% chromium removal rate is achieved. For tests conducted at $\mathrm{pH}$ of 8.5 and 7 , the best efficiencies are obtained at 2 and $3 \mathrm{~A}$ after $14 \mathrm{~min}$. Results reveal that almost similar chromium removal rates are achieved at $\mathrm{pH}$ of $8.5,7$, and 5.5. If the $\mathrm{pH}$ is changed to 5.5 at the beginning of the treatment, the process is accelerated. However, after $14 \mathrm{~min}$ of treatment, 99\% efficiency could be achieved at all three $\mathrm{pH}$ values. Hence, wastewater should be treated at a natural $\mathrm{pH}$ [Espinoza, 2009] to reduce scaling and to avoid using chemicals to adjust $\mathrm{pH}$, thus reducing treatment costs. Espinoza's findings were consistent with Abdalhadi Deghles' findings that at an initial $\mathrm{pH}$ of 8 , an optimum efficiency of $99 \%$ can be achieved. Mella also reports that $98 \%$ $\mathrm{Cr}$ removal was achieved at $\mathrm{pH}$ values above 7.0. This confirms the theoretical predictions from the Pourbaix diagram, wherein $\mathrm{Cr}(\mathrm{OH})_{3}$ precipitation occurs at $\mathrm{pH}$ of $8.0-11$.

\section{Effects from treatment times}

Electrolysis times and metal hydroxide formation are strongly correlated during pollutant removal [Abdalhadi, 2015]. Figures 2 and 3 show that the total chromium removal efficiency increases with increasing treatment time. In most samples, after 14 min of treatment, efficiencies exceed $90 \%$; at $2 \mathrm{~A}$, efficiencies reach $100 \%$. Long treatment times increase energy and electrode consumption [Kobya, 2006]; therefore, an optimal treatment time must be determined.

\section{Experimental design results}

Table 3 presents the response surface for the $3^{\mathrm{k}}$ factorial design; 27 experiments were conducted by varying $\mathrm{pH}$, current intensity, and time. Equation 5 denotes the quadratic regression model obtained using the Statgraphics Centurion XVI software. This model is used to determine the effects of the independent variables $\left(\mathrm{x}_{1}, \mathrm{x}_{2}\right.$, and $\left.\mathrm{x}_{3}\right)$ and their influence on the response variable $\left(\mathrm{y}_{1}\right)$. Table 4 shows ANOVA results at a confidence interval of $95 \%$, wherein the statistical summary model focuses on the $\mathrm{R}^{2}$ correlation coefficient. For total chromium removal, this coefficient reports a value of $85.3584 \%$, which indicates a good model adjustment. Thus, time, current intensity, and $\mathrm{pH}$ are significant at a confidence level of $\mathrm{p}<0.05$.

$$
\begin{aligned}
& y_{1}=430.531+23.1111 x_{1}+2.45238 x_{2}-112.617 x_{3}- \\
& -7.55556 x_{1}^{2}-1.22619 x_{1} x_{2}+5.5 x_{1} x_{3}-0.0963719 x_{2}^{2}+ \\
& +0.626984 x_{2} x_{3}+6.2716 x_{3}^{2}
\end{aligned}
$$

Figure 4 shows model adjustment by representing values obtained using the design model and experimental values; acceptable correlation is observed for total chromium removal 
a)

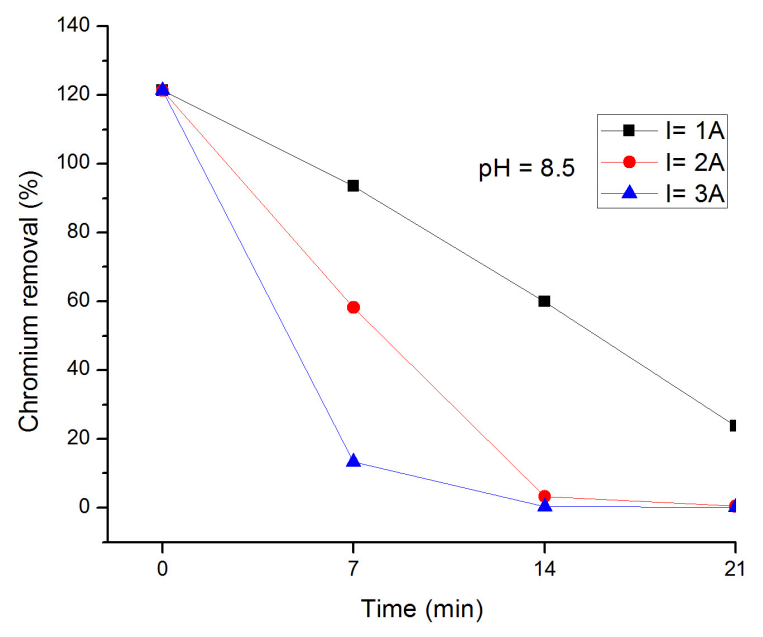

b)

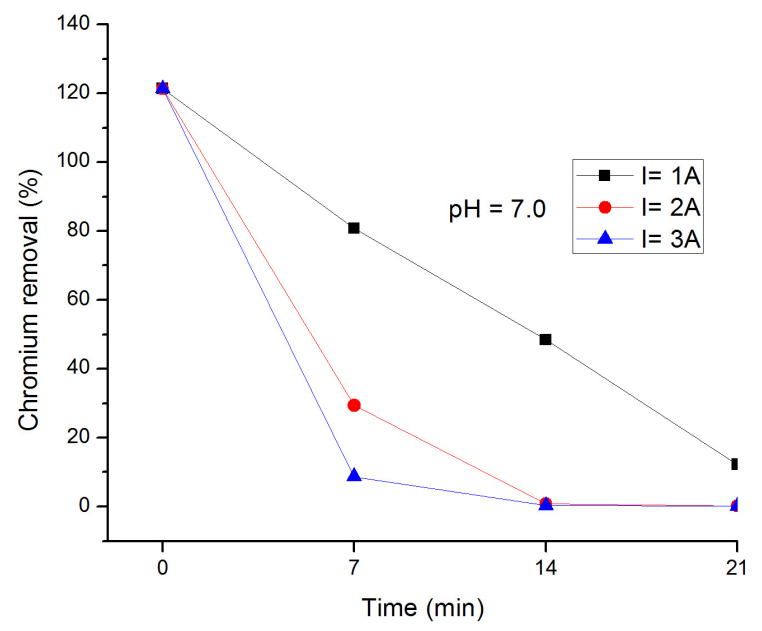

c)

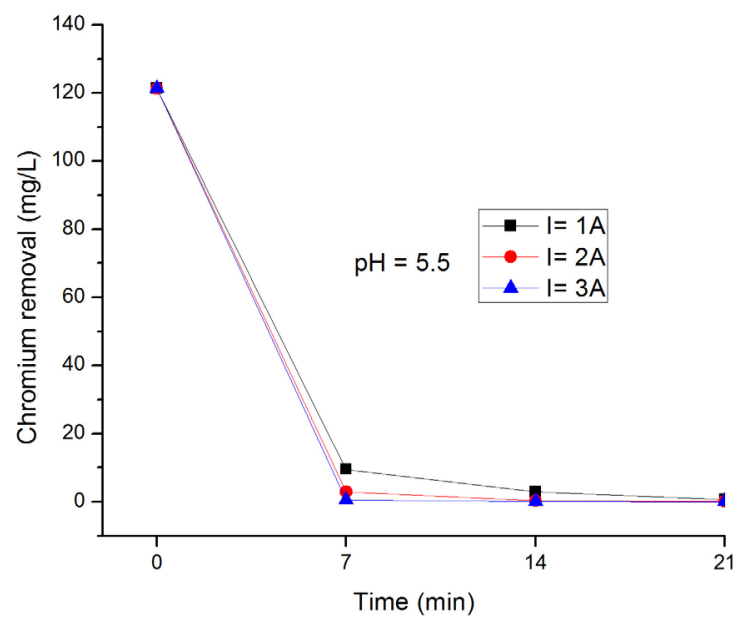

Figure 2. Total chromium variation as a function of time at different current intensities. Total chromium $\mathrm{C}_{0}=123.1897 \mathrm{mg} / \mathrm{l}$; a) $\mathrm{pH}=8.5$; b) $\mathrm{pH}=7$; c) $\mathrm{pH}=5.5$

Table 3. Experiment design using chromium removal as response variable

\begin{tabular}{|c|c|c|c|c|c|c|c|c|c|c|c|c|c|c|}
\hline \multirow{3}{*}{$\begin{array}{l}\text { Exp. } \\
\text { No. }\end{array}$} & \multicolumn{3}{|c|}{ Factors } & \multirow{2}{*}{$\begin{array}{c}\text { Chromium } \\
(\%) \\
\text { removal }\end{array}$} & \multirow{3}{*}{$\begin{array}{c}\text { Exp. } \\
\text { No. }\end{array}$} & \multicolumn{3}{|c|}{ Factors } & \multirow{2}{*}{$\begin{array}{c}\text { Chromium } \\
(\%) \\
\text { removal }\end{array}$} & \multirow{3}{*}{$\begin{array}{l}\text { Exp. } \\
\text { No. }\end{array}$} & \multicolumn{3}{|c|}{ Factors } & \multirow{2}{*}{$\begin{array}{c}\text { Chromium } \\
(\%) \\
\text { removal }\end{array}$} \\
\hline & I (A) & $\mathrm{T}(\mathrm{min})$ & $\mathrm{pH}$ & & & I (A) & $\mathrm{T}(\min )$ & $\mathrm{pH}$ & & & I (A) & $\mathrm{T}(\min )$ & $\mathrm{pH}$ & \\
\hline & $X_{1}$ & $x_{2}$ & $X_{3}$ & y & & $x_{1}$ & $x_{2}$ & $x_{3}$ & $y$ & & $X_{1}$ & $x_{2}$ & $x_{3}$ & $y$ \\
\hline 1 & 1 & 7 & 5.5 & 92 & 10 & 1 & 7 & 7 & 23 & 19 & 1 & 7 & 8.5 & 33 \\
\hline 2 & 1 & 14 & 5.5 & 98 & 11 & 1 & 14 & 7 & 51 & 20 & 1 & 14 & 8.5 & 60 \\
\hline 3 & 1 & 21 & 5.5 & 99 & 12 & 1 & 21 & 7 & 80 & 21 & 1 & 21 & 8.5 & 90 \\
\hline 4 & 2 & 7 & 5.5 & 98 & 13 & 2 & 7 & 7 & 52 & 22 & 2 & 7 & 8.5 & 76 \\
\hline 5 & 2 & 14 & 5.5 & 99 & 14 & 2 & 14 & 7 & 97 & 23 & 2 & 14 & 8.5 & 99 \\
\hline 6 & 2 & 21 & 5.5 & 99 & 15 & 2 & 21 & 7 & 100 & 24 & 2 & 21 & 8.5 & 99 \\
\hline 7 & 3 & 7 & 5.5 & 99 & 16 & 3 & 7 & 7 & 89 & 25 & 3 & 7 & 8.5 & 93 \\
\hline 8 & 3 & 14 & 5.5 & 99 & 17 & 3 & 14 & 7 & 99 & 26 & 3 & 14 & 8.5 & 99 \\
\hline 9 & 3 & 21 & 5.5 & 99 & 18 & 3 & 21 & 7 & 99 & 27 & 3 & 21 & 8.5 & 99 \\
\hline
\end{tabular}


Table 4. Total chromium ANOVA table

\begin{tabular}{|l|c|c|c|c|c|}
\hline \multicolumn{1}{|c|}{ Variation Source } & Sum of Squares & DF & MS & F-Test & P-Value \\
\hline$\chi_{1}:$ Current Intensity (A) & 3640.89 & 1 & 3640.89 & 32.56 & 0.0000 \\
\hline$\chi_{2}:$ Time (min) & 2520.5 & 1 & 2520.5 & 22.54 & 0.0002 \\
\hline$\chi_{3}: \mathrm{pH}$ & 1027.56 & 1 & 1027.56 & 9.19 & 0.0075 \\
\hline$x_{1}^{2}$ & 342,519 & 1 & 342,519 & 3.06 & 0.0981 \\
\hline$\chi_{1} x_{2}$ & 884,083 & 1 & 884,083 & 7.91 & 0.0120 \\
\hline$\chi_{1} x_{3}$ & 816.75 & 1 & 816.75 & 7.31 & 0.0151 \\
\hline$x_{2}^{2}$ & 133,796 & 1 & 133,796 & 1.20 & 0.2892 \\
\hline$\chi_{2} \chi_{3}$ & 520,083 & 1 & 520,083 & 4.65 & 0.0456 \\
\hline$x_{3}^{2}$ & 1194.74 & 1 & 1194.74 & 10.69 & 0.0045 \\
\hline Total Error & 1900.71 & 17 & 111,807 & & \\
\hline Total & 12981.6 & 26 & & & \\
\hline$R^{2}=85.3584 \%, R^{2}$ adj $=77.607 \%$ & & & & & \\
\hline
\end{tabular}

a)

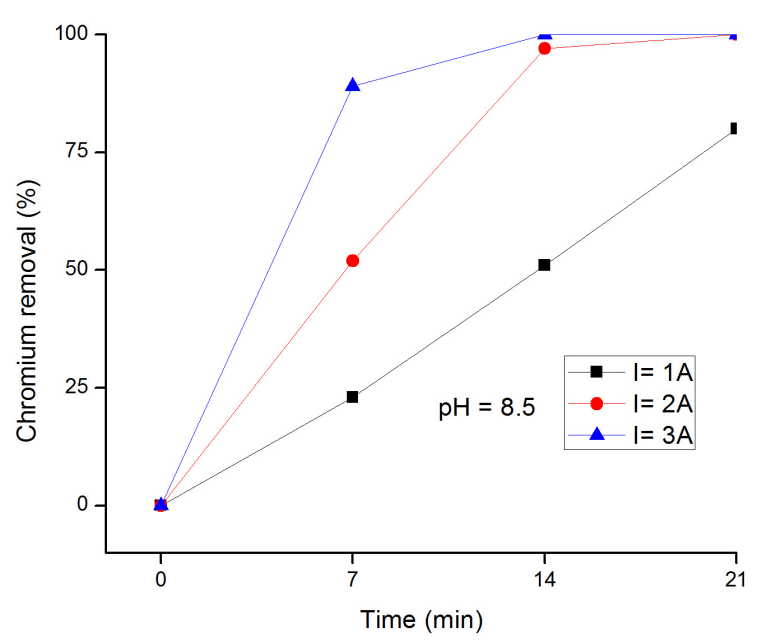

b)

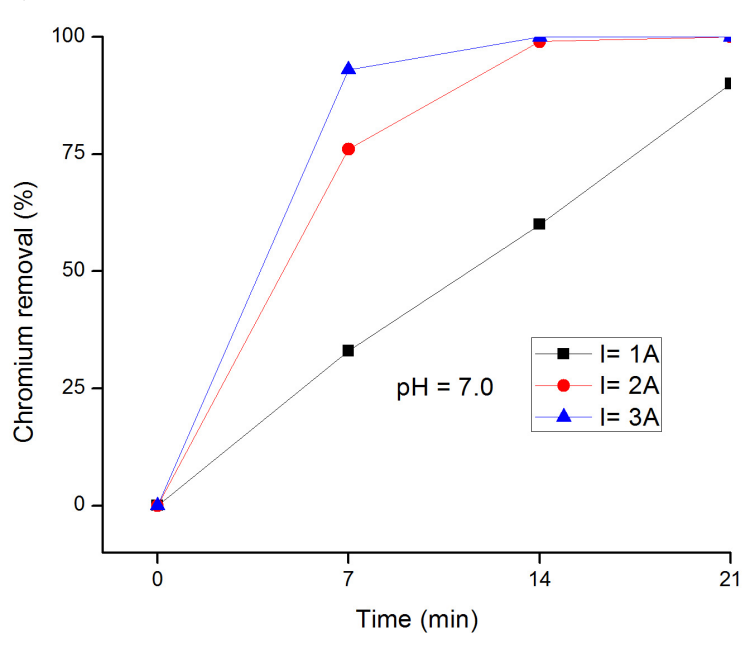

c)

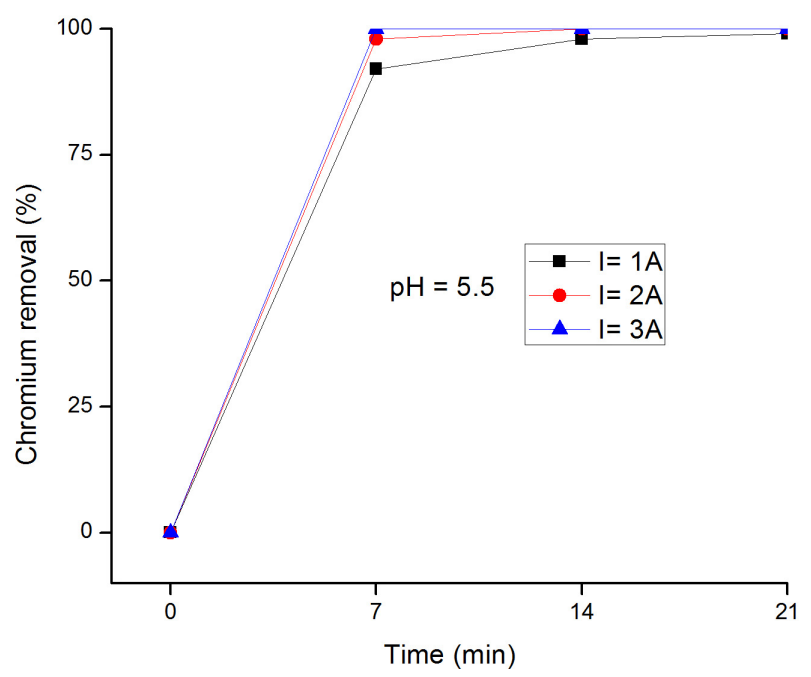

Figure 3. total chromium removal percentage as a function of time.

Total chromium $\mathrm{C}_{0}=123.1897 \mathrm{mg} / \mathrm{l}$; a) $\mathrm{pH}=8.5$; b) $\mathrm{pH}=7$; c) $\mathrm{pH}=5.5$ 


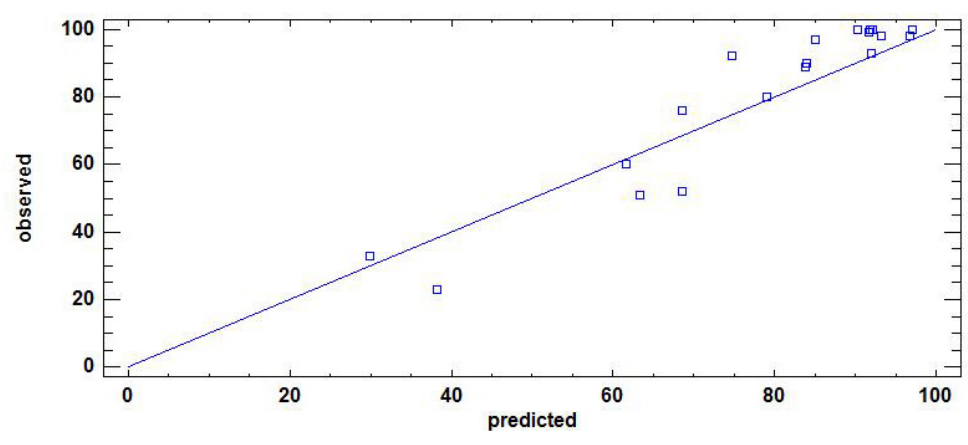

Figure 4. Total chromium removal: predicted vs. observed values

a)

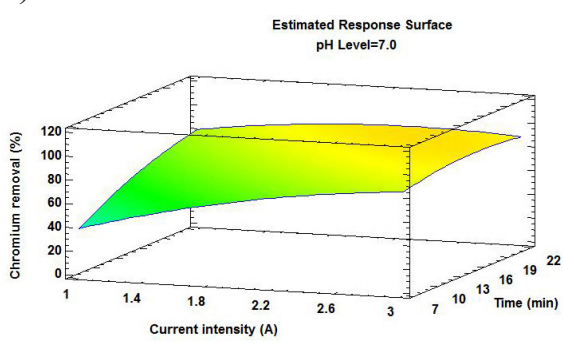

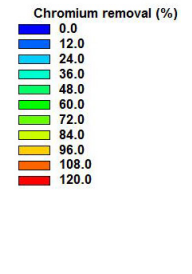

b)

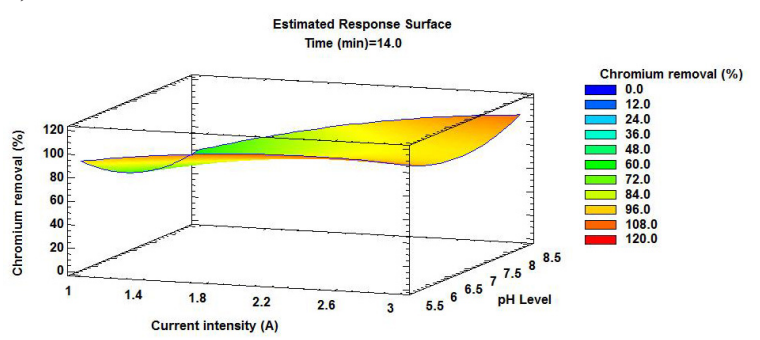

c)

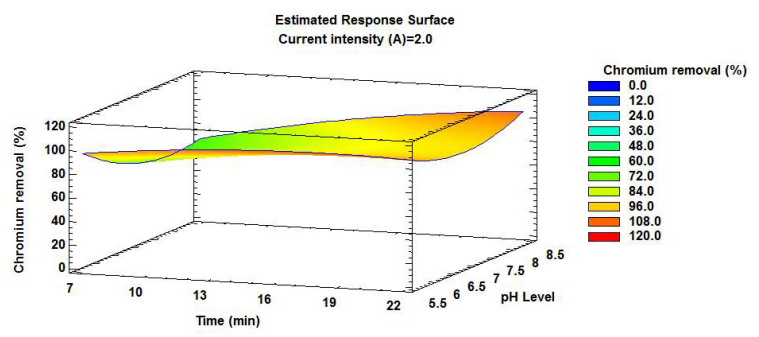

Figure 5. Three-dimensional response surface charts and contours for total chromium removal percentages:

a) Current intensity and time; b) Current intensity and $\mathrm{pH}$; and c) Time and $\mathrm{pH}$

$\left(\mathrm{R}^{2}=0.8535\right)$. Figure 5 shows the response surface charts and variance prediction contours, where the total chromium removal percentage varies based on the variation in current intensity $\left(\mathrm{x}_{1}\right)$, time $\left(\mathrm{x}_{2}\right)$, and $\mathrm{pH}\left(\mathrm{x}_{3}\right)$.

\section{CONCLUSIONS}

This study demonstrated that using aluminum electrodes as anode and cathode, $99 \%$ of the total chromium found in raw tannery wastewater can be removed via electrocoagulation. Results reveal that current intensity, treatment time, and $\mathrm{pH}$ values were significant and affected the response variable (total chromium removal). A correlation coefficient $\left(\mathrm{R}^{2}=0.8535\right.$ was obtained, implying that the proposed statistical model explains $85.3584 \%$ of the variability in the total chromium removal ratio. Highest removal percentages were rapidly obtained at $\mathrm{pH}$ of 5.5 after 14 min of treatment; however, at $\mathrm{pH}$ of 8.5 and 7 , almost similar efficiency values were obtained. Therefore, under actual treatment conditions, using reagents for changing $\mathrm{pH}$ values would not be justified because similar efficiencies were obtained. Further, a current intensity of $2.9 \mathrm{~A}$, a pH of 8.4, and treatment time of $21 \mathrm{~min}$ were the optimum operation conditions for effectively removing total chromium from raw tannery wastewater.

\section{Acknowledgements}

The authors thank the Scientific Research Institute of the University of Lima for promoting the integral development of this project and Center for Productive Innovation and Technological Transfer of Leather and Footwear (CITEccal Lima). 


\section{REFERENCES}

1. Abdalhadi D. and Ugur K. 2015. Treatment of raw tannery wastewater by electrocoagulation technique: optimization of effective parameters using Taguchi method. Desalination and Water Treatment, 57, 14798-14809. DOI:10.1080/19443994.2015.1 074622.

2. Bacardit A., Morera J., Ollé L., Bartolí E. \& Borràs $\mathrm{M}$. 2008. High chrome exhaustion in a nonfloat tanning process using a sulphonic aromatic acid. Chemosphere, 73, 820-824. DOI: 10.1016/j. chemosphere.2008.07.036.

3. Bensadok K., Benammar S., Lapicque F. \& Nezzal G. 2007. Electrocoagulation of cutting oil emulsions using aluminium plate electrodes. Journal of Hazardous Materials, 152, 423-430. DOI:10.1016/j. jhazmat.2007.06.121.

4. Cañizares P., Jiménez C., Martínez F., Rodrigo M.A. \& Sáez C. 2009. The $\mathrm{pH}$ as a key parameter in the choice between coagulation and electrocoagulation for the treatment of wastewaters, Journal of Hazardous Materials, 163, 158-164.

5. Elabbas N., Ouazzani L., Mandi F., Berrekhis M., Perdicakis S., Pontvianne M. N., Pons F. \& Lapicque J. P. 2016. Treatment of highly concentrated tannery wastewater using electrocoagulation: influence of the quality of aluminium used for the electrode. Journal of Hazardous Materials, 319, 69-77. DOI: 10.1016/j.jhazmat.2015.12.067.

6. El-Naas H. \& Hamdan S. 2014. Removal of hexavalent chromium from groundwater by continuous electrocoagulation. International Conference on Chemical Engineering and Applications, 20, 27752781. DOI: 10.7763/IPCBEE. 2014. V74. 16.

7. Espinoza-Quiñones F. R., Fornari M. M. T., Módenes A. N., Palácio S. M., Da Silva F. G., Szymanski N. \& Trigueros D. E. G. 2009. Pollutant removal from tannery effluent by electrocoagulation. Chemical Engineering Journal, 151, 59-65. DOI: 10.1016/j. cej.2009.01.043.

8. Gil Pavas E., Dobrosz-Gómez I. \& Gómez-García M. Á. 2011. The removal of the trivalent chromium from the leather tannery wastewater: the optimisation of the electro-coagulation process parameters. Water Science and Technology, 63, 385-394. DOI: 10.2166/wst.2011.232.

9. Gutiérrez J.F., Espino A.E., Coreño A., Acevedo F.J., Reyna G., Fernández F.J., et al. 2010. Mecanismos de interacción con cromo y aplicaciones biotecnológicas en hongos. Revista Latinoamericana de Biotecnologia Ambiental y Algal, 1, 47-63.

10. Hamdan S.S. \& El-Naas M.H. 2014. Characterization of the removal of Chromium (VI) from groundwater by electrocoagulation. Journal of Industrial and Engineering Chemistry, 20, 2775-2781. DOI: 10.1016/j.jiec.2013.11.006.
11. Harminder P.S. et al. 2013. Chromium toxicity and tolerance in plants. Environmental. Chemistry Letters, 11, 229-254. DOI: 10.1007/ s10311-013-0407-5.

12. Kanagaraj J., Senthivelan T., Panda R.C., Kavitha S. 2014. Eco-friendly waste management strategies for greener environment towards sustainable development in leather industry: A comprehensive review. Journal of Cleaner Production.

13. Kobya M., Hiz H., Senturk E., Aydiner C. \& Demirbas E. 2006. Treatment of potato chips manufacturing wastewater by electrocoagulation. Desalination, 190, 201-211. DOI: 10.1016/j.desal.2005.10.006.

14. Mahmad M., Rozainy M., Abustan I. \& Baharun N. 2016 . Electrocoagulation process by using aluminium and stainless-steel electrodes to treat total chromium, colour and turbidity. Procedia Chemistry, 19, 681-686. DOI: 10.1016/j.proche.2016.03.070.

15. Manjushree C., Mostafa M.G., Biswas T.K. \& Saha A. K. 2013. Treatment of leather industrial effluents by filtration and coagulation processes, Water Resources and Industry.

16. Mella B., Glanert A. \& Gutterres M. 2015. Removal of chromium from tanning wastewater and its reuse. Process Safety and Environmental Protection, 95, 195-201. DOI: 10.1016/j.psep.2015.03.007.

17. Mella B., Glanert A.C.C. \& Gutterres M. 2013. Removal of chromium from tanning wastewater by chemical precipitation and electrocoagulation. In: XXXII Congress of the IULTCS, Istanbul.

18. Mollah M., Morkovsky P., Gomes J., Kesmez M., Parga J. \& Cocke D. 2004. Fundamentals, present and future perspectives of electrocoagulation. Journal of Hazardous Materials, 114, 199-210. DOI: 10.1016/j.jhazmat.2004.08.009.

19. Piña M., Martín A., González C., Prieto F., Guevara A. \& García J. 2011. Revisión de variables de diseño y condiciones de operación en la electrocoagulación. Revista Mexicana de Ingeniería Química, 10, 257-271. Recuperado de http://www. scielo.org.mx/scielo.php?script $=$ sci_arttext\&pid= S1665-27382011000200010.

20. Porras Á.C. 2010. Descripción de la nocividad del cromo proveniente de la industria curtiembre y de las posibles formas de removerlo. Revista Ingenierías Universidad De Medellin, 9, 41-49.

21. Saxena G., Chandra R. \& Bharagava RN. 2016. Environmental pollution, toxicity profile and treatment approaches for tannery wastewater and its chemical pollutants. Reviews of Environmental Contamination and Toxicology, 240, 31-69. DOI: 10.1007/398_2015_5009.

22. Ziati M. 2018. Reduction of turbidity and chromium content of tannery wastewater by electrocoagulation process. Water Environment Research. DOI: 10.21 75/106143017x15131012152906. 